\title{
Field Investigation of Indoor Thermal Performance in Malaysia Air-Welled Terraced House
}

\author{
Pau Chung Leng \\ Faculty of Built Environment and Surveying, Universiti Teknologi Malaysia, 81310 UTM Johor Bahru, Johor \\ Email: pcleng2@utm.my \\ Roshida Abdul Majid, Noraslinda Abdul Rahman \\ Faculty of Built Environment and Surveying, Universiti Teknologi Malaysia, 81310 UTM Johor Bahru, Johor \\ Dilshan Remaz Ossen \\ Architecture Engineering Department, Kingdom University, , 40434 Kingdom of Bahrain \\ Farhana Mohd Razif \\ School of Housing, Building and Planning, Universiti Sains Malaysia, 11800 Penang, Malaysia
}

\begin{abstract}
This paper aims to determine the performance of the air well system in a hot and humid tropical climate with existing full-scale air well of single-storey terraced house. The application of air well in residential building widely applied in a traditional building, especially in the Middle East and Europe countries. However, resulted from the development, the application of passive cooling strategies such as air well is gradually replaced by a mechanical cooling system. The aim of the study is to investigate the cooling system role in tropics, where hot and humid climate the overheating of building interior are a critical dilemma due to solar penetration through building fenestration. A field measurement has been carried out in a single storey terraced house with built-in air well in Kuching, Sarawak for 5 days. The field measurement investigates the thermal performance of the single-storey terrace house air well under tropical context. The investigation was measured with U-12 HOBO data logger for temperature and humidity while the air velocity was measured with HD32.3 DeltaOhm measurement logger. Both types of the instrument placed in the air well in a vertical position while another U12 HOBO datalogger placed in a test room with window connected to air well. The outdoor weather data set were measured with HOBO U30. Findings show that the under Malaysia tropical climate, the mean air velocity induced by the air well throughout the measurement days marked as $0.91 \mathrm{~m} / \mathrm{s}$ while during the hottest hour of the measurement days, the air velocity induced in the upper air well could reach $1.09 \mathrm{~m} / \mathrm{s}$ with an outdoor air temperature of $33.6^{\circ} \mathrm{C}$ and solar radiation of $198 \mathrm{Wh} / \mathrm{m}^{2}$. The findings of the study have explained the effectiveness of the air well in providing the thermal performance in the indoor environment and further study on modification of the air well configuration could enhance the airflow and air temperature.
\end{abstract}

(C) 2019 Penerbit UTM Press. All rights reserved

\section{Article History}

Received : 26 March 2019

Received in revised form : 30 July 2019

Accepted : 04 August 2019

Published Online : 31 August 2019

Keywords:

Air Well, Natural Ventilation, Tropical

Climate, Terraced House, Thermal performance

\section{Corresponding Author Contact:}

pcleng2@utm.my

DOI: $10.11113 /$ ijbes.v6.n3. 388 


\section{Introduction}

The advantages of air well are widely recognized and practice backdated to 900AD. The employment of natural ventilation developed since the existence of vernacular architecture. The principle of the air well effect is functioning assisted by the solar energy and wind-driven ventilation. By creating the temperature gradient between the top of the air well and the room environment, air movement could be induced from the external via inlet (room's window) to outlet (the roof-top opening of air well). Other than air well, the principle of the stack ventilation applied widely in passive cooling strategies such as solar chimney, Trombe wall, solar roof and so forth (Agung Murti \& Mohd Hamdan, 2006; Gan, 1998; Sacht, Bragana, \& Almeida, 2013; Zhai, Dai, \& Wang, 2005). Those passive cooling strategies functioning based on the indoor-outdoor ambient air temperature gradient could be found mainly in the vernacular and traditional domestic buildings, which have already withstood time. The research developed based on the traditionally-existent natural cooling techniques are basically reliable and potentially to be developed since it were growing based on the ancestors experience by generations as responses to the climatic environment. (Paul, 2006) However, the application of air well was slowly diminishing with the introduction of air conditioning system in the industrialized 19th and 20th centuries. The global awareness of the importance of sustainable issues and fossil fuel crisis have leading the building industry into a worldwide view with the application of passive cooling strategies as the effective and efficient strategies to induce natural cooling into the indoor habitable environment. (Wong, Tan, Ang, Mok, \& Goh, 2012). Thus, this paper intended to investigate the effectiveness of air well in tropical climate terraced houses of Malaysia which could be the potential passive cooling strategy that benefiting the occupants of domestic building.

\section{Literature Review}

Literature reviews have studied the advantages, the workability, the mechanism and parameters of solar assisted stack ventilation shaft such as solar chimney, courtyard, air well and so forth (Agung Murti \& Mohd Hamdan, 2006; Gan, 1998; Chen, 2009 ; Zhai, Dai, \& Wang, 2005). The solar assisted stack ventilation could be studied with several methods; namely empirical models, analytical models, zonal models, multizone models, Computational Fluid Dynamic (CFD) models and experimental models. (Chen, 2009).

In Malaysia, Nugroho and Ahmad (Agung Murti \& Mohd Hamdan, 2006) has studied on the possibilities of the solar chimney to induce stack ventilation by using a small scaled model with PVC pipe $(0.15 \varnothing \times 3.5 \mathrm{~m})$. He found that the air temperature gradient between the upper and lower levels of the PVC pipe could reach differences of $5^{\circ} \mathrm{C}$ under Malaysia tropical climate. (Hirunlabh, Kongduang, Namprakai, \& Khedari, 1999) has studied on the use of metallic on solar wall as solar updraft natural ventilation tool. The findings show that the temperature within the metallic solar wall increasing with wall height and decreasing with air gap. Tareq and Ossen has (Tareq G. Farea \& Ossen, 2013) found that the lightwell can be functioning as the heat removal building component as the lightwell adjacency room has lower air temperature compared to the street adjacency room. The highest air temperature gradient between the upper and lower part of the light well in a five storey high apartment during the daytime under clear sky condition was about $2{ }^{\circ} \mathrm{C}$. Air temperature gradient between the upper and lower part of ventilation shaft during the hot day shows that the hot air is updrafted by solar energy.

Wong et al. (Wong et al., 2012) has investigated the performances of full scale solar chimney system under tropical climate in Singapore. The findings show that the solar chimney can induce average air velocity of $1.5 \mathrm{~m} / \mathrm{s}$ within the solar chimney and $0.4 \mathrm{~m} / \mathrm{s}$ in the classroom during the low solar irradiance day. Bassiouny and Koura (Bassiouny \& Koura, 2008) studied on the parameters of solar chimney. He found that the chimney width has a more significant effect on air change rate compared to chimney inlet size. The increase of inlet size three times only improved the air change rate by $11 \%$ while increasing the chimney width by three times could increase the air change rate to $25 \%$.

N.K. Bansal et al. (N.K.Bansal, Rajesh Mathur, \& M.S.Bhandari, 1993) has developed a steady state numerical model for solar chimney which is designed to enhance the solar induced ventilation in building. Different sizes of solar chimney inlet openings with varying discharge coefficients were tested. The mathematical calculations shows that the solar collector with area of $2.25 \mathrm{~m}^{2}$ could induce $140 \mathrm{~m}^{3} / \mathrm{hr}$ to $330 \mathrm{~m}^{3} / \mathrm{hr}$ of air flow for solar radiation of $200 \mathrm{~W} / \mathrm{m}^{2}$ and $1000 \mathrm{~W} / \mathrm{m}^{2}$. Mathur et al. (Mathur, Bansal, Mathur, Jain, \& Anupma, 2006) has investigated on a small scale solar chimney and the findings show that the air flow rate increases with the ratio between absorber height and air gap. There is a potential to induce 55 to $150 \mathrm{~m}^{3} / \mathrm{h}$ air flow rate for 300 to $700 \mathrm{~W} / \mathrm{m}^{2}$ solar radiation incidents on the vertical surface for a typical room with size. $27 \mathrm{~m}^{3}$.

Ren et al. (Ren et al.,2019) has studied the fluid flow and heat transfer mechanism in solar chimney which regulated by thermal buoyancy via numerical studies and experiment investigations. The findings show that the temperature on the heated wall is not distributed evenly which is useful for the solar energy utilization in building energy conservation.

Frutos Dordelly at al has studied the impact of integrating Phase Change Material (PCM) into the solar chimney. The studies show that the solar chimney prototype integrated with PCM could enhance the ventilation rate and the storage of energy for 6 hours. This shows that the effect of heat gain and storage ensured the solar chimney function accordingly (Frutos Dordelly et al., 2019).

Asadi et al has studied on the (Asadi et al, 2016) the effect of orientation on the performqance of solar chimney layout with EnergyPlus software. The findings show that east-southern part of the building position suitable for solar chimney orientation.

Rattanongphisat, Imkong and Khunkong have experimenting the used of square steel on solar chimney for building ventilation application in order to enhance the temperature differences in the horizontal plane on chimney. The air temperature differences in horizontal plance across solar chimney width could up to $7^{\circ} \mathrm{C}$ while the gradient air temperature on vertical direction could up 
to $1.4^{\circ} \mathrm{C}$. The highest air flow near the black durface is up to $0.26 \mathrm{~m} / \mathrm{s}$. The finding contributes to low height type of chimney (Rattanongphisat, Imkong and Khunkong, 2017).

Khosravi, Fazelpour and Rosen have studied on the enhanced application of solar chimney on two-story building via mathematical model approach. The results show that the application of inclined solar chimney would increase the ventilation rate by $24 \%$ compared to conventional solar chimney design (Khosravi, Fazelpour and Rosen, 2019).

The selected literatures stated above have previewed the effectiveness of the ventilation shaft, such as solar chimney and light well. The literature reviews stated above scientifically presented that ventilation shaft is a useful passive ventilation tool which provide thermal comfort for occupants, especially in tropical climate. The significant variables contributed to the effectiveness of solar chimney includes the geometry and configurations of solar chimney, the innovation and integration of solar chimney with absorber materials, the inclination of solar chimney angle as well as the gradient temperature of solar chimney. In this study, the thermal performance of the selected case study single storey terraced house with air well under Malaysia tropical climate was investigated. The studies focusing on the investigation of thermal performance of existing bulding prior to the modification steps of air well to solar chimney in order to examine the vertical temperature and thermal performance of the passive ventilation tool

\section{Research Method}

A single storey terraced house with air well, which located at Kuching, Sarawak, East Malaysia was studied from 18 November
2013 to 22 November 2013. The case studied house has been selected based on its building layout and size as well as the numbers of room provided in the house is falls within the range of the typical size according to Toe, D. H. C terraced house classification studies (Toe, D. H. C, 2013). The main purpose of the study is to investigate the thermal performance of the air well in a single storey terraced house and its effect to the adjacency room. Air movement could reduce the thermal discomfort of the indoor environment, especially in the tropics with high air temperature and high air humidity. However, in Malaysia, the low value of indoor air velocity, which range from 0.04 $0.47 \mathrm{~m} / \mathrm{s}$ (Hui, 1998) could not satisfied the thermal comfort of the occupants. This is due to the inappropriate design layout of the modern terraced house, where the factors of space optimization for marketing demand and value are being prioritized. Most of developers and designers solving the ventilation problem of the bedroom by providing single sided opening for ventilation. The solution, however, still failed to fulfill the needs of daylighting and ventilation of the occupants which eventually ended up with installing the mechanical ventilation system. The terraced house layout with air well attached to the bedroom believed to be effective in providing bedroom with natural ventilation and daylighting.

In this study, the case model focuses on the air well $(2 \mathrm{~m}$ in depth $\mathrm{x} 1 \mathrm{~m}$ in length $\mathrm{x} 5 \mathrm{~m}$ in height) and adjacency room ( $3 \mathrm{~m}$ in length $\mathrm{x} 3 \mathrm{~m}$ in width $\mathrm{x} 3 \mathrm{~m}$ in height). The case model is in a $3 \mathrm{~m}$ ceiling height single storey house measuring $14.1 \mathrm{~m}$ in length and $6 \mathrm{~m}$ in width as shown in Figure 1.

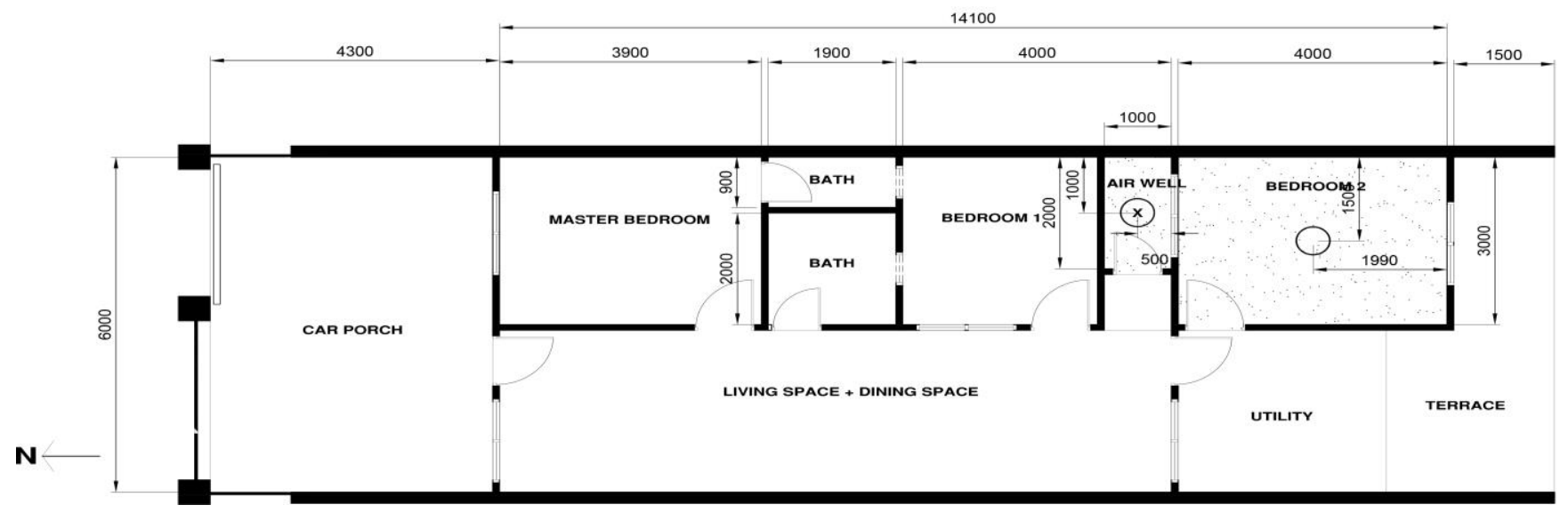

Figure 1 Location of measuring tools with symbol $(\mathrm{O}),(\mathrm{x})$ and $(\Delta)$ are marked above. The $(\mathrm{O})$ represents HOBO U12 air temperature and relative humidity data logger, (x) represents HD32.3 Delta Ohm measurement logger while $(\Delta)$ represents the HOBO U30 outdoor weather station. *The hatced zone with scattered dots represents the study focus area (Source: Author) 


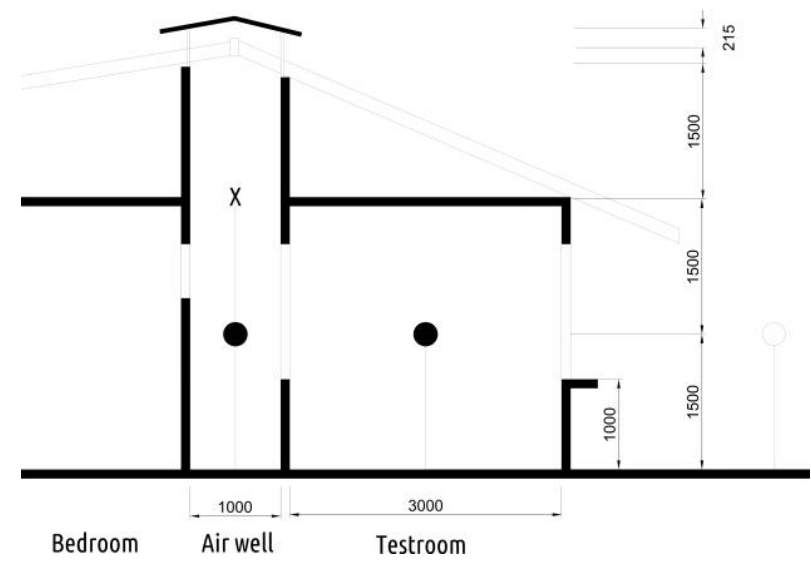

2(a)

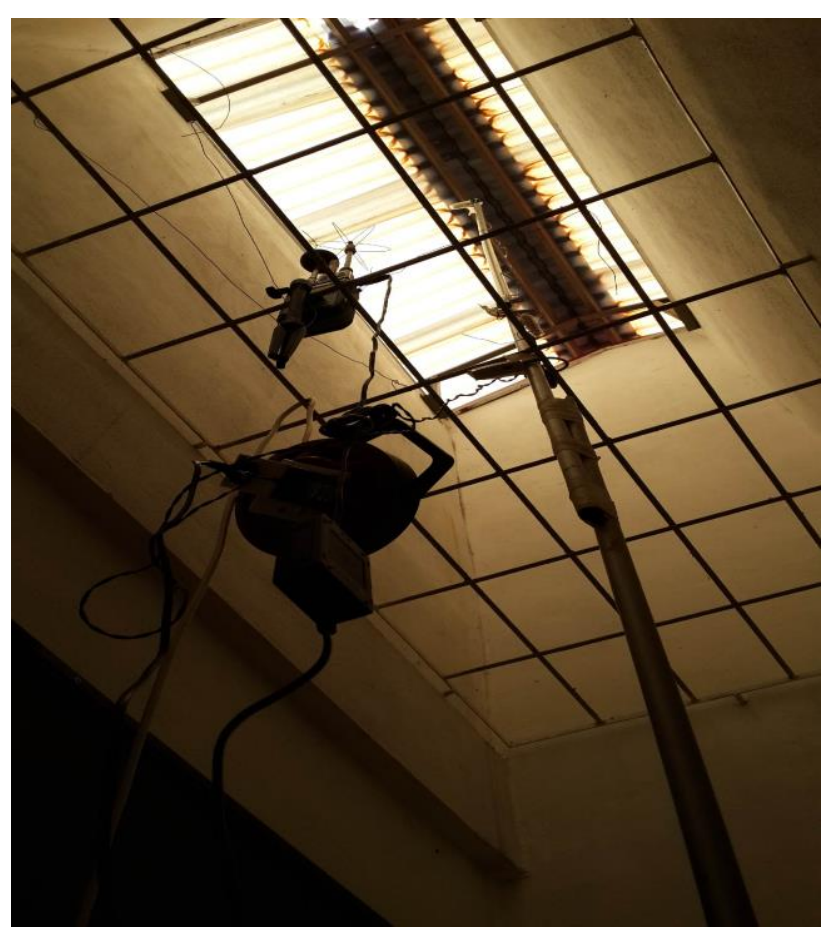

2(b)

Figure 2 (a) and (b). The section drawing of the air well and test room in case study house. The $(\bullet)$ represents the position of the measuring point of $\mathrm{HOBO} \mathrm{U} 12$ air temperature and relative humidity data logger, which is $1.5 \mathrm{~m}$ from floor level while (x) represents the HD32.3 Delta Ohm measurement logger placed $4.5 \mathrm{~m}$ from floor. The photograph shows the location of $\mathrm{C}$ (Source: Author
As seen in Figure 1, the study area only focuses on the air well and test room (hatched with scattered dots). The air well is located bedroom 1 and bedroom 2(test room). It is functioning as the ventilation and daylighting shaft for bedroom 1 and airflow passageway for bedroom 2. The inlet (window at test room) is placed $1.0 \mathrm{~m}$ above floor level with an opening of $1.2 \mathrm{~m}$ by $1.5 \mathrm{~m}$ in width and height. The air well is made up of $100 \mathrm{~mm}$ thick brick wall with both side plastered, having a width and depth measuring $2.0 \mathrm{~m}$ by $1.0 \mathrm{~m}$ respectively. The outlet measures $4.5 \mathrm{~m}$ in total height from floor level and air escapes from the internal window to the roof top of air well with $100 \%$ opening, which shaded with the polycarbonate roofing material to prevent the penetration of rain water. Under the solar radiation, the hot air in the air well expands and the pulling effect of air is generated. The ambient air is forced into the interior through the inlet opening. With the Malaysia tropics climate conditions, the air well system hopes to provide air flow in the test room from the stack effect which induced along the air well shaft.

Table 1 Field experiment setup for measuring tools

\begin{tabular}{|c|c|c|c|c|}
\hline Space & Data Type & Equipment & $\begin{array}{l}\text { Time } \\
\text { Intervals }\end{array}$ & $\begin{array}{l}\text { Measuring } \\
\text { Point (center } \\
\text { point of the } \\
\text { room) }\end{array}$ \\
\hline Outdoor & $\begin{array}{ll}\text { - } & \text { Air } \\
& \text { temperatu } \\
& \text { re } \\
\text { - } & \text { Relative } \\
& \text { humidity } \\
\text { - } & \text { Solar } \\
& \text { radiation } \\
\text { - } & \text { Wind } \\
& \text { speed }\end{array}$ & 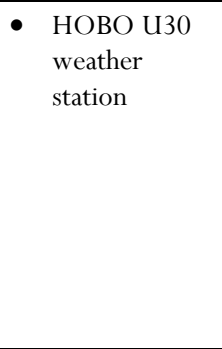 & $\begin{array}{ll}-15 \\
\text { minu } \\
\text { tes } \\
\text { inter } \\
\text { val }\end{array}$ & $\begin{array}{l}1.5 \mathrm{~m} \text { from } \\
\text { floor level }\end{array}$ \\
\hline \multirow[t]{2}{*}{ Air Well } & $\begin{array}{ll}- & \text { Air } \\
\text { temperat } \\
\text { ure } \\
\text { - } & \text { Relative } \\
\text { Humidity }\end{array}$ & 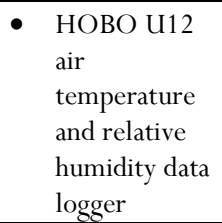 & $\begin{array}{ll}-15 \\
\text { minu } \\
\text { tes } \\
\text { inter } \\
\text { val }\end{array}$ & $\begin{array}{l}1.5 \mathrm{~m} \text { from } \\
\text { floor level }\end{array}$ \\
\hline & - Air speed & $\begin{array}{l}\text { - HD32.2 Delta } \\
\text { Ohm } \\
\text { measurement } \\
\text { data logger }\end{array}$ & $\begin{array}{l}15 \\
\text { minu } \\
\text { tes } \\
\text { inter } \\
\text { val }\end{array}$ & $\begin{array}{l}3.0 \mathrm{~m} \text { from } \\
\text { floor level }\end{array}$ \\
\hline $\begin{array}{l}\text { Test } \\
\text { Room }\end{array}$ & $\begin{array}{ll} & \text { Air } \\
\text { temperat } \\
\text { ure } \\
\text { - } \\
\text { Relative } \\
\text { humidity }\end{array}$ & $\begin{array}{l}\text { HOBO U12 } \\
\text { air } \\
\text { temperature } \\
\text { and relative } \\
\text { humidity data } \\
\text { logger }\end{array}$ & $\begin{array}{l}15 \\
\text { minu } \\
\text { tes } \\
\text { inter } \\
\text { val }\end{array}$ & $\begin{array}{l}1.5 \mathrm{~m} \text { from } \\
\text { floor level }\end{array}$ \\
\hline
\end{tabular}

The HOBO $\mathrm{U} 12$ air temperature and relative humidity data logger and HD32.2 Delta Ohm measurement data logger were placed at the center of the air well at $1.5 \mathrm{~m}$ (point B) and $3.0 \mathrm{~m}$ (point C) height from the floor level respectively (As shown in Figure 2(a) and 2(b). Another HOBO U12 air temperature and relative humidity data logger placed at $1.5 \mathrm{~m}$ level (point A) in order to investigate the thermal performance of the test room. The HOBO U30 weather station was set up on site to obtain the 
outdoor weather climate condition as reference. The height of $1.5 \mathrm{~m}$ considered as human sensory height, whereas the air speed data logger placed at $3.0 \mathrm{~m}$ in order to investigate the ventilation performance of the air well. The data set from outdoor weather station is important, as the reference set for the thermal performance of the air well and test room. All readings were recorded at a logging interval of fifteen minutes, and further averaged over every 4 readings per hour. The sampling period was measured from 12:00am of 18 November 2013 to $11: 45 \mathrm{pm}$ of 22 November 2013. All measurement data were recorded simultaneously from 12:00am of 18 November 2013. Summary of the investigation points of measuring instrument has been listed in Table 1 above. The significance of the investigation study enabled researchers to identify the thermal performance of existing air well in terraced house in Malaysia. Due to the limitation of the exposed outdoor envelope of terraced housing, interior layout of habitable room only allowed single sided ventilation which is not efficient in providing thermal comfort to the occupants. This study has been carried out for one week under the climatic condition with average range of air temperature and relative humidity for past 10 years, hence the outcome of the studies still valid for the future references (Malaysia, 2018)

\section{Results and Findings}

Malaysia's weather is generally characterized by high temperature and humidity whole year round, and accompanied by two significant Monsoon seasons and long period of solar radiation. (Malaysia, 2018) According to the field measurement as shown in Figure 3 and Figure 4, generally Malaysia possesses high temperature and high humidity, which ranged from $23.07^{\circ} \mathrm{C}$ to $37.08^{\circ} \mathrm{C}$ and $48.81 \%$ to $98.03 \%$ respectively , with daily average air temperature of $27.21^{\circ} \mathrm{C}$ and humidity of $83.40 \%$. The average measurement result is fulfilled the range of the average air temperature and humidity recorded by Department of Meteorological Malaysia, which stated $23^{\circ} \mathrm{C}$ to $32^{\circ} \mathrm{C}$, and $85 \%$ respectively. In general, Malaysia's wind speed is light and variable. However the two significant Monsoon seasons, which happened in May to September and November to March, would determine the prevailing wind flow.

The wind speed in Malaysia throughout the year ranged from $5.14 \mathrm{~m} / \mathrm{s}$ to $15.43 \mathrm{~m} / \mathrm{s}$ above $10 \mathrm{~m}$ level. However, the gradient velocity profile at the suburban area slows down wind velocity from upper atmosphere. This is caused by the turbulence due to the uneven landform and obstacles. Thus, according to Figure 4, the highest outdoor wind velocity recorded $1.5 \mathrm{~m}$ above floor recorded as $5.52 \mathrm{~m} / \mathrm{s}$ while the lowest air velocity recorded between 0 to $0.22 \mathrm{~m} / \mathrm{s}$. The insignificant mean outdoor air velocity with value $1.29 \mathrm{~m} / \mathrm{s}$ that could not enhance the ventilation for indoor room has caused the thermal discomfort to the occupants in terraced house. (Malaysia, 2018)

Located close to the equator, Malaysia is gifted with abundant of sunshine. In average, Malaysia receives 5 to 7 hours of sunshine per day, or more than 2200 hours per year. The average annual daily solar irradiations for Malaysia ranged from 4.21 to 5.56 $\mathrm{kWhm}^{-2}$. (Muzathik, 2013) The long hour sunshine and high solar irradiations in Malaysia benefit the performance of solar induced ventilation shaft. Figure 4 indicated that the highest solar radiation recorded as $581 \mathrm{Wh} / \mathrm{m}^{2}$ at 13:00 of 19 November 2013 while the average solar radiation for the field measurement day marked as $290.40 \mathrm{Wh} / \mathrm{m}^{2}$. Solar irradiation is one of the factors influenced the thermal comfort of the buildings. In general, higher solar irradiation would increase the air temperature under the condition air velocity is near zero or static. Hence, in order to stimulate air movement under no wind condition, air temperature differences within a zone could induce stack ventilation to achieve indoor natural ventilation.

The air well plays the role to induce the ventilation via the stack effect. In this field measurement, two set of measuring data logger were placed at $1.5 \mathrm{~m}$ (lower air well) and $3.0 \mathrm{~m}$ (upper air well) to investigate the existence of temperature gradient. According to Figure 5, the temperature differences between air well (upper and lower) and outdoor is significant. The fluctuation range between air well and outdoor air temperature throughout field measurement days registered with total mean air temperature differences of $2.07^{\circ} \mathrm{C}$, which is $4.71 \%$.

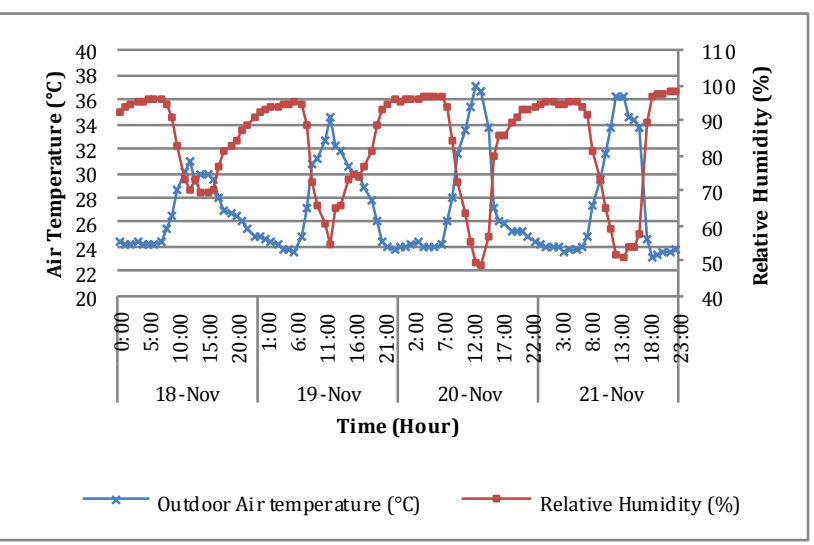

Figure 3 Measured outdoor air temperature and relative humidity from 18 November to 21 November 2013

(Source: Author)

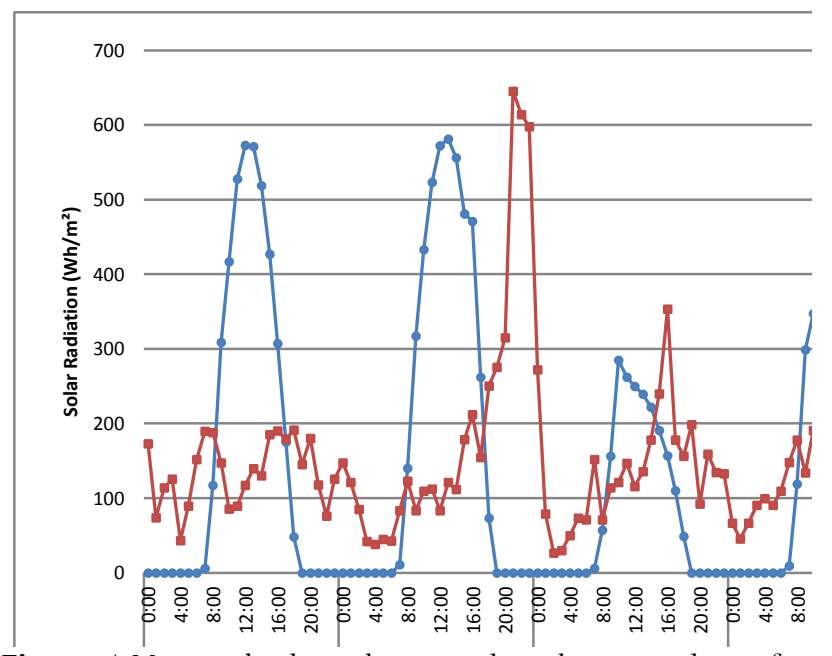

Figure 4 Measured solar radiation and outdoor air velocity from 18 November to 21 November 2013

(Source: Author) 
Although both differences is relative small, which is not compatible with the fluctuated graph pattern in Figure 5, the stability of the air well air temperature fluctuation is higher compared to outdoor air temperature. The air well air temperature fluctuated between $27.97^{\circ} \mathrm{C}$ to $30.92^{\circ} \mathrm{C}$, with differences of $9.54 \%$ while the outdoor air temperature fluctuated between $24.07^{\circ} \mathrm{C}$ to $37.08^{\circ} \mathrm{C}$, with differences of $35.09 \%$. This shows that the air well manage to stabilize and balance the air temperature of the indoor environment, and functioning as ventilation outlet and daylighting provider medium for the room. Similar to air temperature, the air humidity for the air well and test room is also fluctuated within the balance and acceptable range compared to the outdoor air humidity as in Figure 6. The mean air humidity for the overall measurement days recorded as $83.40 \%$ while the test room and air well marked $77.53 \%$ and $76.24 \%$ respectively. The differences between both indoor and outdoor air humidity is $6.52 \%$ (Figure 6). This shows that the air well manages to retain the air humidity and air temperature in relative similar range between day and night time, via the use of sensible heat stored in the air well brick material in the day time and release in the night time, where the surrounded environment is being cooled down.

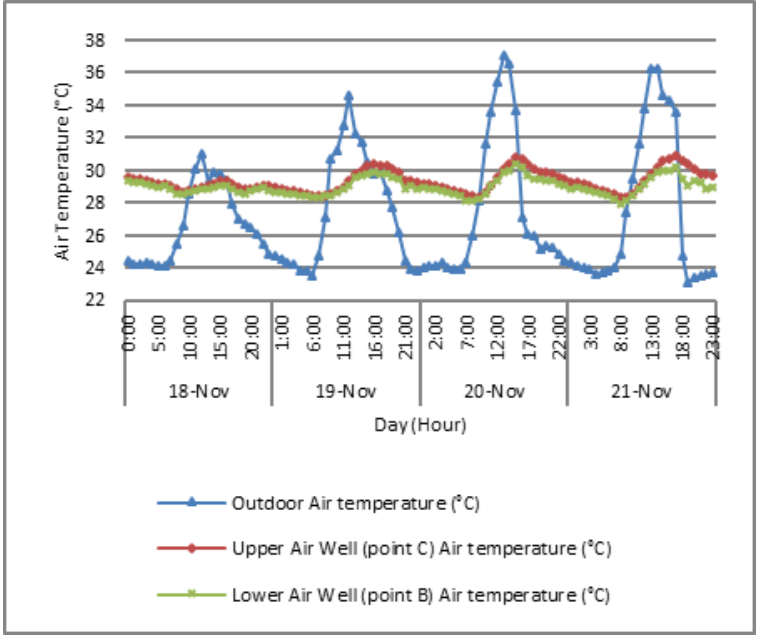

Figure 5 Measured outdoor air temperature, upper air well air temperature and lower air well air temperature from 18 November to 21 November 2013

(Source: Author)

In Figure 7, the wind velocity in the air well is noticeable, which has followed the air temperature pattern of the air well. The average air velocity induced by the air well marked as $0.91 \mathrm{~m} / \mathrm{s}$ throughout the field measurement period. Meanwhile, when the outdoor air temperature marked as $33.6^{\circ} \mathrm{C}$ with solar radiation $198 \mathrm{Wh} / \mathrm{m}^{2}$, the air velocity induced in the upper air well on 20 November of $15: 00 \mathrm{hr}$ registered value of $1.09 \mathrm{~m} / \mathrm{s}$. Another example shown in 20 November 15:00hr, the air flow registered as $0.65 \mathrm{~m} / \mathrm{s}$ with the increase of mean air well air temperature from $29.61^{\circ} \mathrm{C}$ to $30.49^{\circ} \mathrm{C}$. According to Wong et al. (Wong et al., 2012) the solar ventilation shaft able to induce average air velocity of $1.5 \mathrm{~m} / \mathrm{s}$ with air temperature differences of $4^{\circ} \mathrm{C}$. The phenomenon result of this case is similar, which stated the possibility to induce stack ventilation with temperature differences.

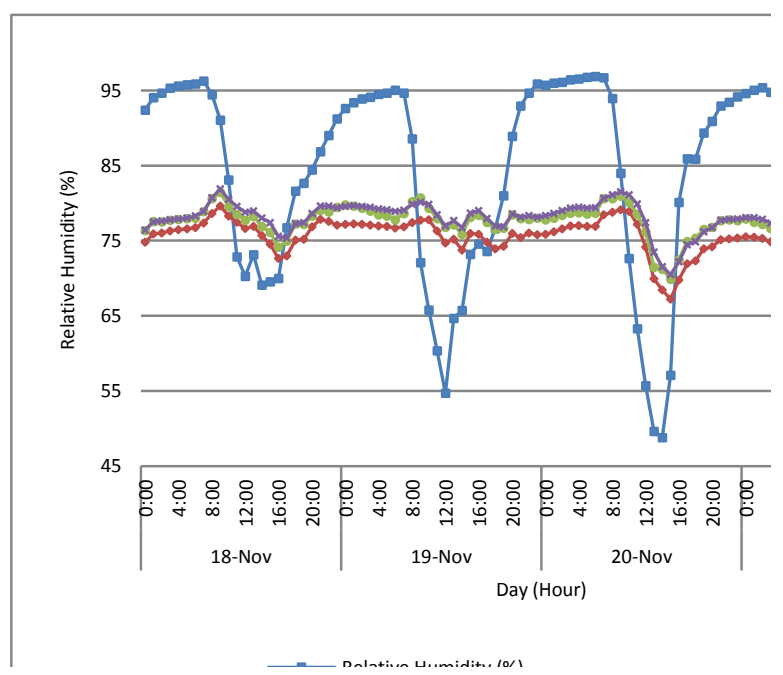

Figure 6 Measured relative humidity of outdoor, upper and lower air well as well as testroom from 18 November to 21 November 2013

(Source: Author)

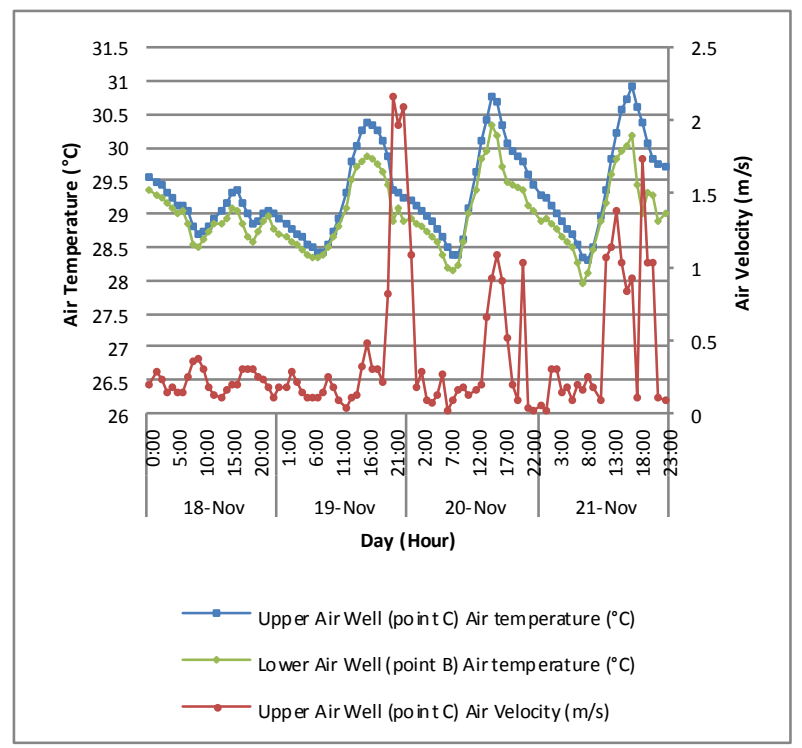

Figure 7 Measured lower and upper air well air temperature as well as upper air well air velocity from 18 November to 21 November 2013

(Source: Author)

For Figure 8, the solar radiation in general has a great influenced on the air temperature patterns. Significantly, the outdoor air temperature flows accordingly to the solar radiation while the upper air well fluctuated based on the outdoor air temperature. The time range of the peak for air temperature and solar radiation recorded as $10: 00 \mathrm{hr}$ to $16: 00 \mathrm{hr}$. The highest value of solar radiation within four days recorded as $581 \mathrm{Wh} / \mathrm{m}^{2}$, while the outdoor air temperature at that time recorded as $32.24^{\circ} \mathrm{C}$. 
However, air temperature for both air well and test room at that time ranged from $29.52^{\circ} \mathrm{C}$ to $29.79^{\circ} \mathrm{C}$, which is $2.64^{\circ} \mathrm{C}$ lower than outdoor air temperature. Air well stabilizes the thermal performance (air temperature) of the indoor environment.

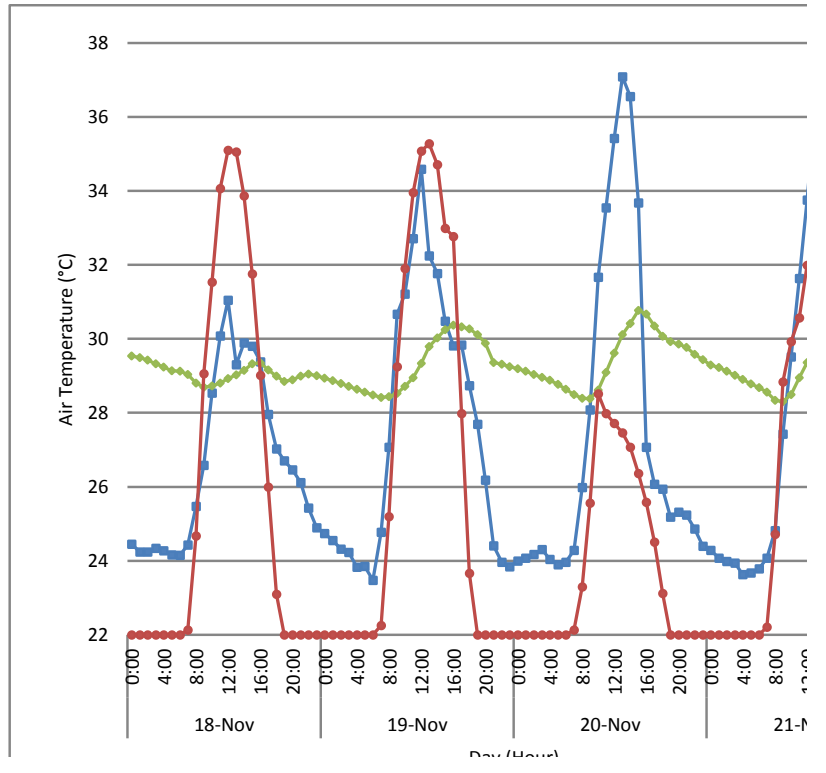

Figure 8 Measured outdoor and upper air well air temperature as well as solar radiation from 18 November to 21 November 2013 (Source: Author)

In Figure 9, the comparison between air temperatures of air well and test room was made. The maximum differences between upper and lower air well diurnal air temperature $(07: 00 \mathrm{hr}$ to 18:00hr) marked as $1.35^{\circ} \mathrm{C}$ while the minimum differences is $0.034^{\circ} \mathrm{C}$. For the outdoor and upper air well air temperature, the maximum differences marked as $7.29^{\circ} \mathrm{C}$ while minimum as $0.031^{\circ} \mathrm{C}$. From the results, the significant maximum and minimum air temperature between the upper air well and outdoor air temperature has revealed that air well plays the role of thermal performance regulator for indoor room. When the maximum mean test room result compared to the air well result, the differences of both areas marked as $2.8^{\circ} \mathrm{C}$.

By managing the field measurement data into the psychometric chart according to ASHRAE Standard 55-2010, the field measurement data of the test room has fulfilled $62.8 \%$ of the adaptive comfort ventilation. Climate consultant 5.5 is free software that helps designer to translate the weather data into graphically display graphs and charts including the psychometric chart. The parameters used for the thermal comfort model is Adaptive Comfort Model in ASHRAE Standard 55-2010. The ASHRAE Standard 55-2010 has been widely applied to measure the thermal comfort of indoor environment in the tropical climate. This could be used to benchmarking the position of thermal comfort of existing terrace house in Malaysia. In general the model is suitable to be applied for the naturally ventilated spaces where fenestration and openings allowed to be opened and closed freely. The model assumes occupants adapt their clothing (1.0 to $1.3 \mathrm{met}$ ) to the thermal environment with sedentary job and no mechanical cooling system used in the measuring room. (Robin Liggett \& Milne, 2008) The adaptive comfort ranged is set between $23.3^{\circ} \mathrm{C}$ to $29.8^{\circ} \mathrm{C}$ with the humidity ratio of 0.012 to 0.025. The adaptive ventilation comfort could be further improved via the modification of air well into solar chimney to induce stack ventilation for terrace house room.

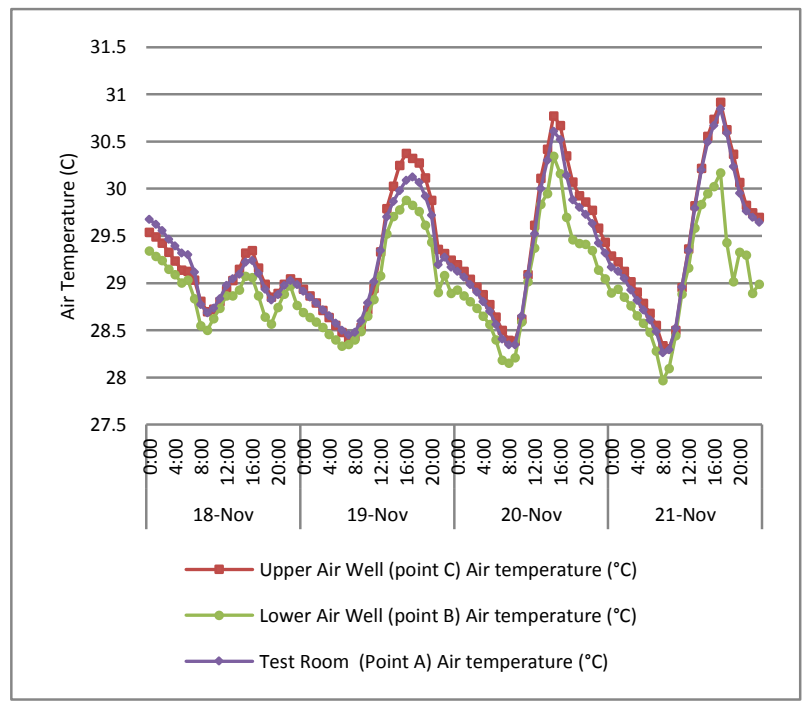

Figure 9 Measured upper and lower air well as well as test room air temperature from 18 November to 21 November 2013

The major concern of the studies are focusing on the potential of the air well in terraced houses, which is mostly exists in terrace house of Malaysia proposed by designer in order to fulfill the compliances of Uniform Building By Law (UBBL) 1984, in Clause 39 (1) under Part III (Space, Light and Ventilation), stated that the requirement by means of one or more windows is required in a total area of not less than $10 \%$ of the clear floor area in a room, and it shall have operable openings not less than $5 \%$ of total floor area (Malaysia. and MDC Legal Advisers., 2000). Designer creates minimum size air well in order to allow natural ventilation and daylighting for the intermediate room.

Since the single sided ventilation strategy is not performing and giving significant impact for the occupants in providing thermal comfort, modification of air well into solar chimney is one of the alternative to promote stack ventilation and increase thermal performance of terraced house habitable room without utilizing the mechanical ventilation system. Malaysia falls within equator zone of the globe and gifted more than 5 hours of solar radiation per day enabled the principle of solar updraft principle works by utilizing the temperature gradient of the solar chimney.

Hence, by conducting this based case study, the extension research could be proceeded by carrying out the modification on air well configurations for better thermal and ventilation performance of the solar chimney. 


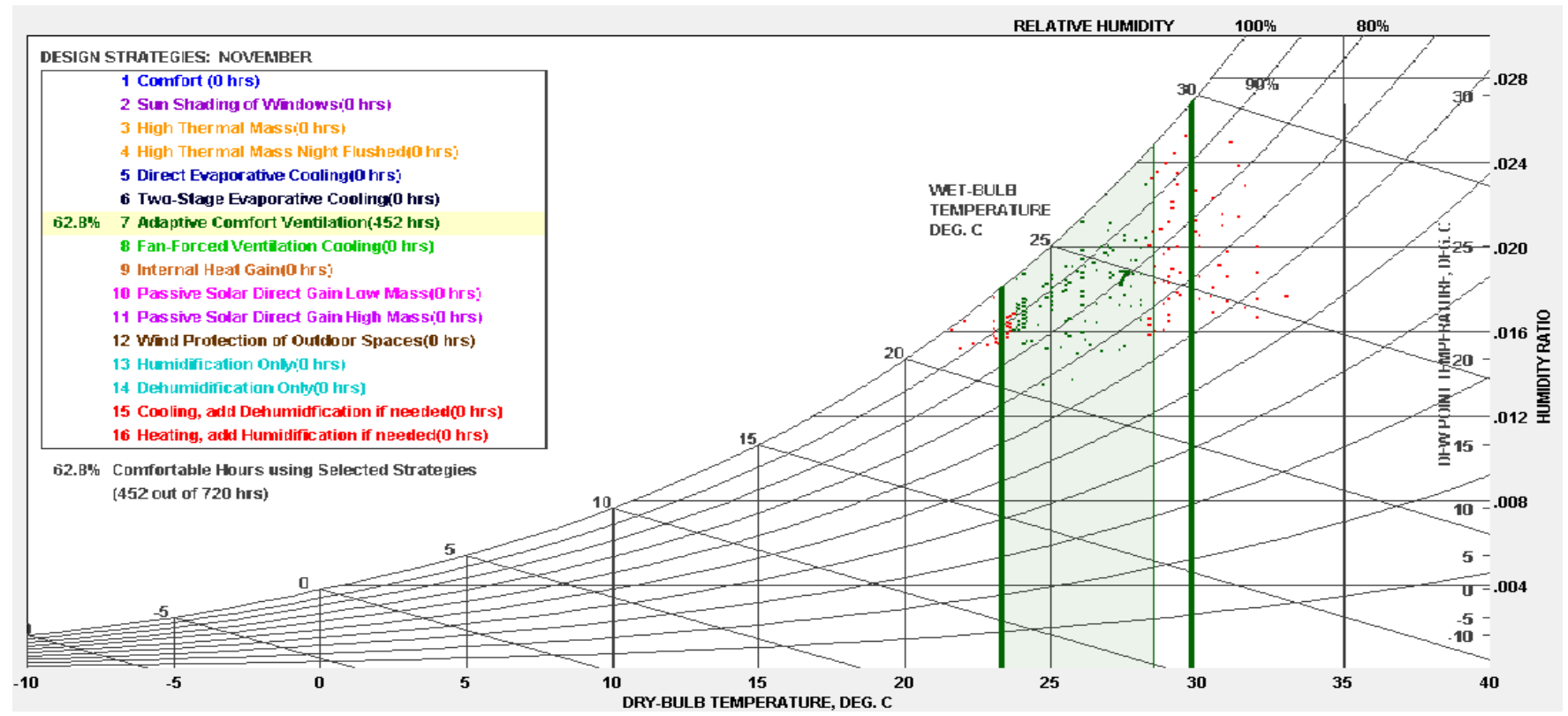

Figure 10 The psychometric chart generated by Climatic Consultant 5.5 shows the overall measuring points obtained in the test room fulfilling 62.8\% of the adaptive comfort ventilation based on Adaptive Comfort Model in ASHRAE Standard 55-2010

(Source: Climatic Consultant 5.5)

\section{Conclusion}

The single storey case study house located in Kuching, Sarawak with air well was studied from 18 November to 21 November 2013. The field measurement carried out in order to investigate the thermal performance of the air well to the test room. Results showed that under Malaysia tropical climate, the mean air velocity induced by the air well throughout the measurement days marked as $0.91 \mathrm{~m} / \mathrm{s}$ while during the hottest hour of the measurement days, the air velocity induced in the upper air well could reach $1.09 \mathrm{~m} / \mathrm{s}$ with outdoor air temperature of $33.6^{\circ} \mathrm{C}$ and solar radiation of $198 \mathrm{Wh} / \mathrm{m}^{2}$. The mean differences of air well and test room of $2.8^{\circ} \mathrm{C}$ has shown that air well as the thermal regulating medium in order to stabilize the air temperature of indoor environment from being fluctuated dramatically as outdoor environment, and providing ventilation passageway and daylighting medium for the indoor room. The existing air well (2m in depth $\mathrm{x} 1 \mathrm{~m}$ in length $\mathrm{x} 5 \mathrm{~m}$ in height) and adjacency room ( $3 \mathrm{~m}$ in length $\mathrm{x} 3 \mathrm{~m}$ in width $\mathrm{x} 3 \mathrm{~m}$ in height) has fulfilled $62.8 \%$ of adaptive comfort ventilation (As shown in Figure 10). Further research is required to determine the enhanced configuration of air well in order to promote stack ventilation in the terraced house.

\section{Acknowledgment}

The authors like to thank Institut Sultan Iskandar for the financial support

\section{References}

Agung Murti, N., and Mohd Hamdan, A. (2006). Possibility to use solar chimney to improve stack ventilation in tropical climate. Journal Alam Bina, 8(1): 77-98.

Asadi, S. et al. (2016). The effect of solar chimney layout on ventilation rate in buildings, Energy and Buildings, 123: 71-78

Bassiouny, R., and Koura, N. S. A. (2008). An analytical and numerical study of solar chimney use for room natural ventilation. Energy and Buildings, 40(5): 865-873.

Chen, Q. (2009). Ventilation performance prediction for buildings: A method overview and recent applications. Building and Environment, 44(4): 848-858.

Frutos Dordelly, J. C. et al. (2019). Experimental analysis of a PCM integrated solar chimney under laboratory conditions, Solar Energy, 188: $1332-1348$

Gan, G. H. (1998). A parametric study of Trombe walls for passive cooling of buildings. Energy and Buildings, 27(1): 37-43.

Hirunlabh, J., Kongduang, W., Namprakai, P., \& Khedari, J. (1999). Study of natural ventilation of houses by a metallic solar wall under tropical climate. Renewable Energy, 18(1): 109-119.

Hui, S. K. (1998). Natural ventilation of low cost dwellings in the hot humid tropics Malaysia. Universiti Teknologi Malaysia, Skudai.

Khosravi, M., Fazelpour, F. and Rosen, M. A. (2019). Improved application of a solar chimney concept in a two-story building: An enhanced geometry through a numerical approach, Renewable Energy, 143: 569-585 
Malaysia, J. M. (2018). General Climate of Malaysia. http://www.met.gov.my/index.php?option $=$ com_content\&task $=$ vie w\&id $=75 \&$ Itemid $=1089 \&$ limit $=1 \&$ limitstart $=2$. Retrieved 30 June 2018.

Malaysia MDC Legal Advisers. (2000) Uniform Building by-Laws 1984: all amendements up to September, 2000, MDC Publishers Printers. Available at: https://www.slideshare.net/JoshuaLee68/ubbl1984-pdf. Retrieved on 30 July 2019.

Mathur, J., Bansal, N. K., Mathur, S., Jain, M., and Anupma. (2006). Experimental investigations on solar chimney for room ventilation. Solar Energy, 80(8): 927-935.

Muzathik, A. M. (2013). Potential of global solar radiation in Terengganu, Malaysia. International Journal of Energy Engineering (IJEE), 3(4): 130-136.

N.K.Bansal, Rajesh Mathur, and M.S.Bhandari. (1993). Solar chimney for enhanced stack ventilation. Building and Environment, 28(3): 373377.

Paul, Oliver. (2006). Built to Meet Needs: Cultural Issues in Vernecular Architecture. Architectural Press, Oxford.

Rattanongphisat, W., Imkong, P. and Khunkong, S. (2017). An Experimental Investigation on the Square Steel Solar Chimney for Building Ventilation Application, Energy Procedia, 138: 1165-1170
Ren, X.-H. et al. (2019). Thermal driven natural convective flows inside the solar chimney flush-mounted with discrete heating sources: Reversal and cooperative flow dynamics, Renewable Energy, 138: 354-367.

Robin Liggett, \& Milne, M. (2008). Climate Consultant 5.5.

Sacht, H. M., Bragana, L., and Almeida, M. (2013). Trombe wall and glazings facades: Energy efficiency for different Portuguese Climates. Informes De La Construccion, 65: 11-22.

Tareq G. Farea, \& Ossen, D. R. (2013). Effect of lightwell combined with horizontal void on natural ventilation in an apartment building. Paper presented at the Proceedings of 4th International Graduate Conference on Engineering, Science and Humanities (IGCESH, 2013), Johor, Malaysia.

Toe, D. H. C. (2013) Application of Passive Cooling Technique to Improve Indoor Thermal Comfort of Modern Urban Houses in HotHumid Climate of Malaysia. Hiroshima University, Hiroshima, Japan

Wong, N. H., Tan, A. Y. K., Ang, K. S., Mok, S., \& Goh, A. (2012). Performance evaluation of solar chimney system in the tropics. Paper presented at the ICSDC 2011: Integrating Sustainability Practices in the Construction Industry - Proceedings of the International Conference on Sustainable Design and Construction 2011.

Zhai, X. Q., Dai, Y. J., and Wang, R. Z. (2005). Experimental investigation on air heating and natural ventilation of a solar air collector. Energy and Buildings, 37(4): 373-381. 